\title{
Take-all of Wheat and Natural Disease Suppression: A Review
}

\author{
Youn-Sig Kwak ${ }^{1 *}$ and David M. Weller ${ }^{2}$ \\ ${ }^{I}$ Department of Applied Biology and Institute of Agriculture \& Life Science, Gyeongsang National University, Jinju 660-701, Korea \\ ${ }^{2}$ United States Department of Agriculture, Agricultural Research Service, Root Disease and Biological Control Research Unit, \\ Pullman, WA 99164-6430, USA
}

(Received on July 23, 2012; Revised on September 19, 2012; Accepted on September 25, 2012)

In agro-ecosystems worldwide, some of the most important and devastating diseases are caused by soil-borne necrotrophic fungal pathogens, against which crop plants generally lack genetic resistance. However, plants have evolved approaches to protect themselves against pathogens by stimulating and supporting specific groups of beneficial microorganisms that have the ability to protect either by direct inhibition of the pathogen or by inducing resistance mechanisms in the plant. One of the best examples of protection of plant roots by antagonistic microbes occurs in soils that are suppressive to takeall disease of wheat. Take-all, caused by Gaeumannomyces graminis var. tritici, is the most economically important root disease of wheat worldwide. Take-all decline (TAD) is the spontaneous decline in incidence and severity of disease after a severe outbreak of takeall during continuous wheat or barley monoculture. TAD occurs worldwide, and in the United States and The Netherlands it results from a build-up of populations of 2,4-diacetylphloroglucinol (2,4-DAPG)-producing fluorescent Pseudomonas spp. during wheat monoculture. The antibiotic 2,4-DAPG has a broad spectrum of activity and is especially active against the take-all pathogen. Based on genotype analysis by repetitive sequence-based-PCR analysis and restriction fragment length polymorphism of phlD, a key 2,4-DAPG biosynthesis gene, at least 22 genotypes of 2,4-DAPG producing fluorescent Pseudomonas spp. have been described worldwide. In this review, we provide an overview of G graminis var. tritici, the take-all disease, Pseudomonas biocontrol agents, and mechanism of disease suppression.

Keywords : 2,4-DAPG, biological control, Gaeumannomyces graminis var. tritici, Pseudomonas spp., take-all decline

\section{Take-all Disease of Wheat}

The pathogen. In South Australia, take-all was recognized as a disease of wheat as early as 1852 (Hornby, 1998). The

\footnotetext{
*Corresponding author.

Phone) +82-55-772-1922, FAX) +82-55-772-1929

E-mail)kwak@gnu.ac.kr
}

pathogen was given the name Ophiobolus graminis in 1881. In 1952, von Arx and Olivier studied the perithecia, asci, and ascospores of the take-all fungus and assigned it to a new genus, Gaeumannomyces, under the order Diaporthales, resulting in its current designation, Gaeumannomyces graminis (Sacc.) von Arx \& Olivier var tritici Walker (Ggt) (Cook, 2003; Hornby, 1998). The fungus can grow between $4^{\circ} \mathrm{C}$ and $30^{\circ} \mathrm{C}$, in a pH range of 3 to 10 , and is homothallic. In culture, the production of hyaline hyphae is later followed by the development of darkly pigmented macrohyphae and curling back of the hyphae at the edge of the colony (Fig. 1A) (Cook, 2003; Freeman and Ward, 2004; Hornby, 1998). Additionally, Ggt produces simple round shape of hyphopodia on wheat coleoptiles (Fig. 1B). Perithecia, produced by Ggt on lower leaf sheaths and stems, contain unitunicate asci with slightly curved ascospores (Fig. 1C); together, they are the major taxonomic features of Ggt. The average size of the ascospore is 70-105 $\mu \mathrm{m} \times 2.5-3 \mu \mathrm{m}$. The optimum temperature for the growth of $G g t$ is $20-25^{\circ} \mathrm{C}$ and growth rate is in the range of $6-10 \mathrm{~mm}$ per day (Freeman and Ward, 2004; Hornby, 1998).

The disease. Take-all generally develops at a soil $\mathrm{pH}$ of 5.5 to 8.5 and is most common where wheat is grown under moist conditions. The hyphae penetrate through the cortex, endodermis and stele, and take in nutrients from the plant. Runner hyphae grow on the surface of roots, both upward and downward, and infect different sites along the root. Plant-to-plant spread of the pathogen occurs via runner hyphae growing through root bridges (Wiese, 1987). Symptoms of take-all include root rot, stunting, yellowing of the plant and nutrient deficiency. In the field, severely infected plants often occur in patches. Take-all produces characteristic black to chocolate brown lesions on the roots (Fig. 1D). Soil moisture is the key factor in the spread of take-all. If soil moisture is limited, symptoms are limited to blackened roots and patches of diseased plants are not typically seen. However, under high precipitation or irrigation the pathogen will spread to the crown and eventually to the culm base, and patches of stunted plants will appear. Infection of the stem disrupts water flow to the plant, finally resulting in 


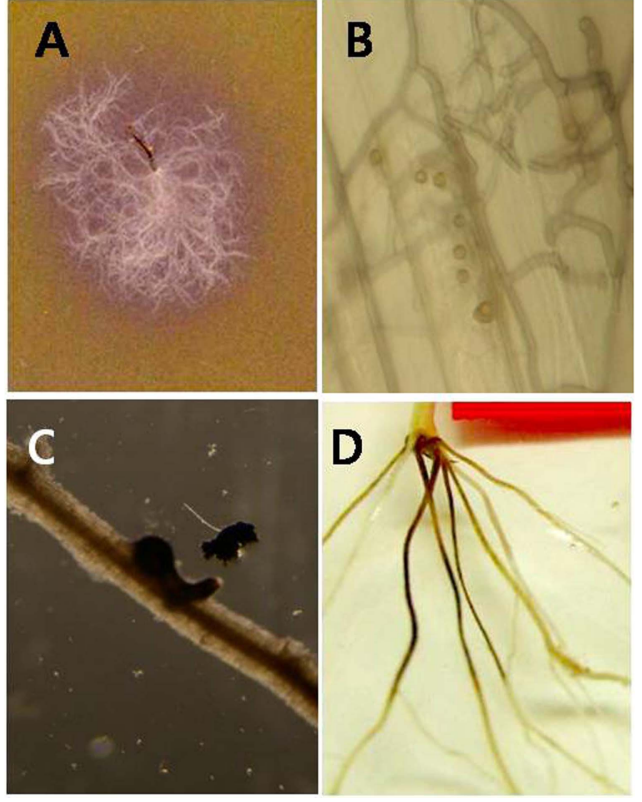

Fig. 1. Symptom of take-all (A), G. graminis var. tritici alters the color of R-PDA from orange to purple (B) and hypopodia formation on wheat coleoptiles by $G$ graminis var. tritici. (C) Perithecia on the infected root. (D) Typically infected root symptom.

premature death of the plants and giving the heads a bleached appearance called "white-heads".

Another type of take-all known as "dryland take-all" occurs under conditions of low precipitation (areas with as little as $250 \mathrm{~mm}$ of annual precipitation) (Cook, 2003). The growth rate of $G$ graminis var. tritici is reduced by half at soil matrix potentials of $-1,500$ to $-2,000 \mathrm{kPa}$. However, the water potentials inside the root can remain suitable for growth of the pathogen much longer than on the surface. Therefore, the disease continues development upward internally to the stem base but with no notable black lesions on the surface of the tillers. With dryland take-all, because of the limitation of moisture every plant must be infected separately from different primary inoculum sources (Cook, 2003). Patches are usually absent in dryland take-all.

As a result of the ability of G. graminis var. tritici to infect wheat grown under both high and low precipitation, take-all is common throughout the world and is the most important soilborne disease of wheat (Cook et al., 1995; Freeman and Ward, 2004; Hornby, 1998; Wiese, 1987). The pathogen also causes root rot of rye, barley and other Poaceae (Cook, 2003; Weller, 1988; Weller et al., 2002). Ggt survives saprophytically as mycelium on infested plant debris and on susceptible grasses (Kollmorgen and Walsgott, 1984). The disease is usually more severe in light-textured soils with low fertility, and at alkaline $\mathrm{pH}$ (Smiley and Cook, 1973). The light textured soil may have two possible effects. First, it may tend to produce a loose seed bed, allowing the pathogen to spread more easily, and second, it may have poor water availability, causing water stress to plant root systems (Moore and Cook, 1984). Application of a high rate of nitrogen increases take-all on the seminal roots during primary infection but decreases take-all severity on crown roots and during secondary infection. Ammonium nitrogen fertilizers decrease disease levels and infection when compared with nitrate nitrogen fertilizer (Smiley and Cook, 1973). Because, take-all is favored by alkaline $\mathrm{pH}$, disease severity decreases as soil $\mathrm{pH}$ declines below 7.0.

As with other soilborne diseases, take-all is difficult to control because resistant wheat varieties are not available. Crop rotation and tillage are effective controls, but because of the limited value of alternative crops in modern cerealbased production systems, 2 or 3 crops of wheat often will be grown before a break, increasing the incidence and severity of take-all. Many growers utilize some form of reduced tillage to control erosion but this practice also exacerbates take-all. Take-all can be completely controlled by the use of soil fumigants such as methyl bromide and chloropicrin, but the cost of the fumigation is not practical for wheat (Cook, 2003) and methyl bromide has been banned because it destroys the ozone layer. Some microtubule assembly inhibitors (benzimidazole and triazole) and sterol biosynthesis-inhibiting fungicides (triadimenol and nuarimol) gave significant control of take-all in naturally infested fields, but the results have been inconsistent and uneconomical for wheat in many places. The fungicide silthiofam (registered in Europe as Latitude ${ }^{\circledR}$ ) has shown promise for take-all control when applied as a seed treatment. Yield increases have been reported with this chemical in China, France, and Kansas (Cook, 2003).

\section{Suppressive Soils and Take-all Decline}

Suppressive soils are defined as "soils in which the pathogen does not establish or persist, establishes but causes little damage, or establishes and causes disease for a while but thereafter the disease is less important even though the pathogen may persist in the soil" (Baker and Cook, 1974; Weller, 1988; Weller et al., 2007). General suppression is a characteristic of essentially all soils to inhibit the growth and activity of soilborne pathogens to a limited extent, owing to the activity of the total microbial biomass in soil competing with the pathogen (Weller et al., 2002; Weller et al., 2007). Specific suppression is highly effective and results from the activity of individual or select groups of microorganisms. General suppression is not transferable between soils, but specific suppression is transferable by adding a small amount of suppressive soil to a conducive soil. Specific suppression can be eliminated by pasteurization $\left(60^{\circ} \mathrm{C}, 30 \mathrm{~min}\right)$ or fumigation of the soil (Weller et 
al., 2002; Weller et al., 2007). Suppressive soils are classified as long-standing (origin of the suppression is not known) or induced. Most suppressive soils have a microbial basis and crop monoculture is one of the primary ways that suppressiveness is induced (Weller et al., 2007).

Take-all decline (TAD), defined as the "the spontaneous decrease in take-all incidence and severity induced by continuous monoculture after a severe outbreak of the disease," is one of the best examples of induced suppressiveness (Cook and Rovira, 1976; Smiley and Cook, 1973; Weller et al., 2002, 2007). TAD has been reported worldwide and many growers depend on TAD to manage take-all (Weller et al., 2002, 2007). The suppressiveness of TAD is transferable (Weller, 1988; Weller et al., 2007); it is eliminated by crop rotation from wheat to non-host crops, and by pasteurization $\left(60^{\circ} \mathrm{C}, 30 \mathrm{~min}\right)$ or fumigation of the soil (Weller et al., 2002). TAD effectively suppresses the development of severe take-all but does not eliminate the disease. Fluctuations in take-all incidence and severity are normal in TAD fields and small take-all patches can occur even in strongly suppressive fields. Many different microorganisms have been hypothesized to play a role in TAD. However, studies in Washington State and The Netherlands have demonstrated that TAD develops because of the buildup of strains in the Pseudomonas fluorescens complex (Loper et al., 2012) that produce the broad-spectrum antibiotic 2,4DAPG $\left(p h l D^{+}\right)$during monoculture of wheat or barley (Raaijmakers and Weller, 1998; 2001; Weller et al., 2007). phlD is an essential gene within the 2,4-DAPG biosynthesis operon and can be detected with the specific primers Phl2a and Phl2b (Raaijmakers et al., 1998; Ramette, 2001) or B2BF and BPR4 (McSpadden Gardener et al., 2001). The terms "2,4-DAPG producing-Pseudomonas" and "phlD Pseudomonas" have been used interchangeably because pseudomonads that contain phlD also produce the antibiotic. The role of 2,4-DAPG producers in TAD was demonstrated when these bacteria were detected on wheat grown in TAD soils at population sizes greater than $10^{5}$ $\mathrm{cfu} / \mathrm{g}$ of root (threshold for take-all suppression) but were not detected or were below the threshold population on wheat grown in conducive soils (Raaijmakers et al., 1999; Raaijmakers and Weller, 2001; Weller et al., 2002). Raaijmakers and Weller (1998) then reported that transfer of a small amount of TAD soil into a conducive soil resulted in establishment of both a threshold density of 2,4DAPG producers and take-all suppressiveness. In addition, elimination of 2,4-DAPG-producers from a TAD soil by pasteurization or crop rotation resulted in a loss of take-all suppression (Raaijmakers and Weller, 1998) (Figs. 2A, 2B). Finally, the antibiotic 2,4-DAPG was isolated from the rhizosphere of wheat grown in TAD soil but not conducive soil (Raaijmakers et al., 1999).
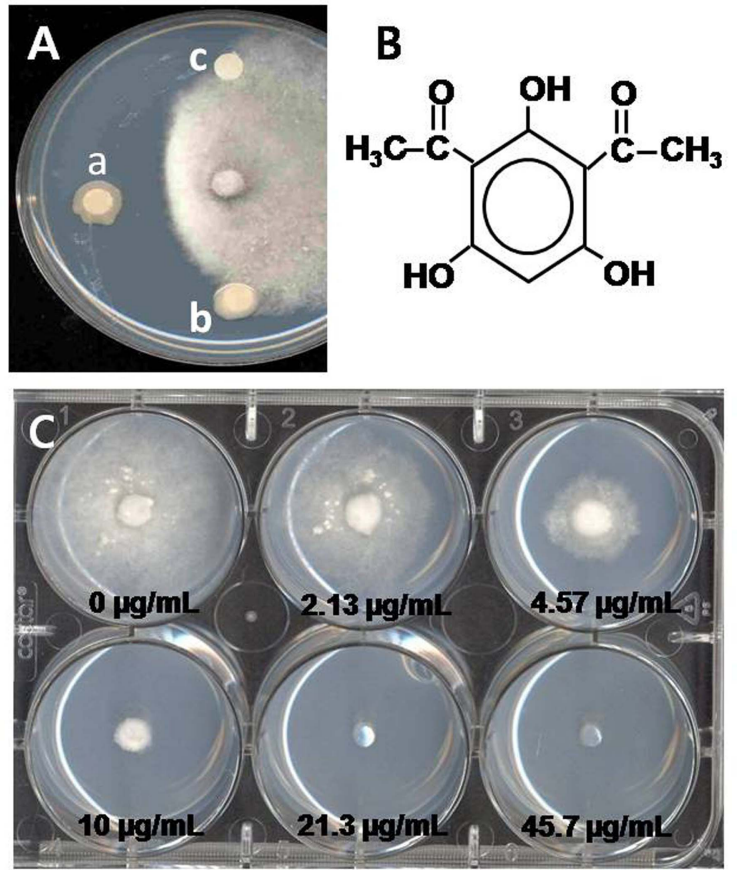

Fig. 2. (A) In vitro inhibition assay of $G$ graminis var. tritici by 2,4-diacetylphloroglucinol-producing $P$. brassicacearum Q8r196 (a), 2,4-DAPG deficient strain 4C5 derived by Q8r1-96 (b) and control (c). (B) structure of 2,4-diacetylphloroglucinol (C) 2,4-DAPG sentitivity assay of $G$ graminis var. tritici, the represent pathogen strains is R3-111a-1.

\section{Biocontrol Agent: Fluorescent Pseudomonas spp.}

Nutrient deficiency commonly causes the death or inactivity of microorganisms in the soil. Therefore, competition for limited nutrients is a major mechanism in the suppression of soilborne fungal pathogens by biocontrol agents. Fluorescent pseudomonads are highly adapted to the rhizosphere and to rapidly utilizing root exudates such as sugars, amino acids and carboxylic acids (Lugtenberg and Kravchenko, 1999; Weller, 2007). This ability is considered to be an important trait for root colonization by most pseudomonads. Prior occupation of key sites on roots by bacteria (niche exclusion) preventing pathogen colonization of the root is also a mechanism of biocontrol and a component of competition. Nutrient competition and niche exclusion are not unique characteristics of biocontrol pseudomonads; even strains without biocontrol activity compete for nutrients and space (Haas et al., 2002; Haas and Keel, 2003).

Peudomonads produce high-affinity iron chelating agents called siderophores under iron deficient conditions (Calvent et al., 2001), and this is another example of competition leading to biocontrol. Siderophores transport soluble ferric iron from the soil into the bacterial cell. Siderophores are excreted and bind iron (III), which is then taken up by the 
bacteria. The fluorescent pigment (pyoverdine) produced by fluorescent pseudomonads is a high affinity siderophore and one of the best studied Pseudomonas siderophores. Siderophores chelate iron and suppress the growth of fungal pathogens by starving them for iron (Chet and Inbar, 1994). Siderophores are also involved in the synthesis of some volatile antibiotic compounds. For example, a siderophore mutant $\left(p v d^{-}\right)$of $P$. fluorescens CHA0 produced less $\mathrm{HCN}$ than the wild type, probably because $\mathrm{HCN}$ synthesis requires iron (Thomashow, 1996).

Many Pseudomonas spp. implicated in biological control produce one or more antibiotic compounds (Fravel, 1992; Haas and Défago, 2005; Weller et al., 2007). Antibiosis is defined as "antagonism mediated by specific or nonspecific metabolites of microbial origin, by lytic agents, enzymes, volatile compounds, or other toxic substances" (Fravel, 1992). Antibiotics produced by Pseudomonas spp. can inhibit the growth of fungal pathogens and they can also have broad-spectrum activity against other organisms such as bacteria and nematodes, and can be phytotoxic (Haas and Keel, 2003; Keel et al., 1992; Weller et al., 2007). Phenazines, phloroglucinols, pyoluteorin, pyrrolnitrin, cyclic lipopeptides and hydrogen cyanide are some of the most common antibiotics produced by Pseudomonas spp., and the genes involved in their synthesis and roles in biocontrol are well characterized (Haas and Défago, 2005; Mavrodi et al., 2006a).

Phenazines are a large class of heterocyclic nitrogen-containing compounds with broad-spectrum antibiotic activity (Mavrodi et al., 2006a) and are inhibitors of electron transport in the animal cell (Ran et al., 2003). Phenazinedeficient $\left(P h z^{-}\right)$mutants lost the ability to inhibit $G$. graminis var tritici and failed to suppress take-all on wheat (Cook, 2003; Thomashow and Weller, 1988). 2,4-Diacetylphlorogucinol $(2,4-\mathrm{DAPG})$ is the best described antibiotic member of the phloroglucinol compounds. de Souza et al. (2003a) demonstrated that 2,4-DAPG caused membrane damage and inhibited swimming, encystment, and disintegration of zoospores of Pythium. 2,4-DAPG produced by $P$. fluorescens has antifungal, antibacterial, antihelminthic and phytotoxic activity (Weller et al., 2002). It is highly inhibitory $\left(\mathrm{ED}_{90}=5.04 \mu \mathrm{g} / \mathrm{ml}\right)$ to G. graminis var. tritici (Kwak et al., 2009) (Fig. 2C).

P. fluorescens Pf-5, now known as P. protegens (Loper et al., 2012), produces a very broad range of antimicrobial compounds. The genome of this strain was the first of any biocontrol agent sequenced (Paulsen et al., 2005), and analysis of the genome showed that nearly $6 \%$ of the genes are dedicated to production of antimicrobial compounds (Loper and Gross, 2007). Pyoluteorin produced strain Pf-5 and other pseudomonads were shown to have a role in the suppression of Pythium damping-off (Maurhofer, 1995); however, the mechanism of its action is not known (Haas and Défago, 2005). Pyrrolnitrin, also produced by strain Pf5 and other Pseudomonas spp., has a broad spectrum of activity and its production was responsible for the suppression of damping-off of cotton and cucumber caused by Rhizoctonia solani (Hammer et al., 1997). Pyrrolnitrin is a fungal respiratory chain inhibitor. It has been applied as an antibiotic in human medicine, particularly against dermatophytic fungi of the genus Trichophyton, and a derivative of it also has been developed as a fungicide (Ligon et al., 2000).

Biocontrol pseudomonads also produce biosurfactants as a mechanism of pathogen suppression. For example, Pseudomonas sp. DSS73 was isolated from sugar beet roots and it had strong antagonistic activity against Pythium ultimum and Rhizoctonia solani. A cyclic lipopeptide (CLP), amphisin, produced by strain DSS73 functions both as a biosurfactant and has antifungal activity (Andersen et al., 2003). Zoosporicidal activity against Pythium spp. was attributed to $P$. fluorescens strain R1SS101 (de Souza et al., 2003a; Raaijmakers et al., 2006). Pseudomonas strain CMR12a suppressed Rhizoctonia root rot on bean (Phaseolus vulgaris) and produced phenazine-1-carboxylic acid and phenazine-1-carboxamide as well as CLP surfactants (D'aes et al., 2011). Mutants deficient in either phenazine or CLP production were significantly less suppressive of Rhizoctonia root rot than the parental strain, and a double mutant deficient in production of both kinds of compounds completely lost its biocontrol activity. The results suggested that the two classes of antagonistic molecules functioned additively in these studies (D'aes et al., 2011). Phytopathogenic Pseudomonas spp. also produce cyclic lipopeptides, which are able to perturb membrane function (Haas and Défago, 2005).

Hydrogen cyanide (HCN) is produced by many Pseudomonas biocontrol agents that suppress soilborne pathogens. $\mathrm{HCN}$ generally inhibits metalloenzymes, such as coppercontaining cytochrome c oxidases (Haas and Défago, 2005). HCN-producing P. protegens (P. fluorescens) CHA0 protects tobacco plants from the black root rot pathogen, Thielaviopsis basicola. P. fluorescens strain P3 does not produce $\mathrm{HCN}$ naturally and gives poor plant protection against the pathogen. However, when an artificial transposon carrying the cyanide biosynthetic gene ( $h c n)$ was transformed into strain P3, the recombinant strain synthesized cyanide and had greater suppression of black root rot (Voisard et al., 1989).

\section{Biocontrol By 2,4-DAPG-producing Psudomonas spp.}

Genetic diversity of 2,4-DAPG-producing Pseudomonas spp. 2,4-DAPG-producing pseudomonads of the $P$. fluore- 
scens complex (Loper et al., 2012) provide biocontrol of a wide variety of root and seedling diseases on many different crops. For example, strain CHA0 suppressed black root rot of tobacco, crown and root rot of tomato, Pythium damping-off of cucumber and take-all of wheat (Duffy and Défago, 1997; Keel et al., 1992; Schnider et al., 1995; Stutz et al., 1986). Pseudomonas strain F113 suppressed Pythium root rot of sugar beet and cyst nematode and soft rot of potato (Cronin et al., 1997a; 1997b). P. brassicacearum (formerly P. fluorescens) strain Q8r1-96 (Loper et al., 2012) and $P$. fluorescens strain SSB17 suppressed take-all (de Souza et al., 2003b; Raaijmakers and Weller, 1998). $P$. fluorescens strain Q2-87 is a biocontrol agent of both takeall and crown and root rot of tomato (Pierson and Weller, 1994; Weller et al., 2002). The genetic and phenotypic diversity present within 2,4-DAPG-producing $\left(p h l D^{+}\right)$strains of the P. fluorescens complex (Loper et al., 2012) has been studied extensively. For example, phylogenetic analysis performed based on $16 \mathrm{~S}$ ribosomal DNA revealed 3 phylogenetic groups designated amplified ribosomal DNA restriction analysis (ARDRA) groups 1, 2, and 3 (McSpadden Gardener et al., 2000; Weller et al., 2007). ARDRA groups 1 and 2 were distinguished by the ability to produce pyrrolnitrin, to utilize certain carbon sources and to deamidate 1aminocyclopropane-1-carboxylic acid (Wang et al., 2001). Pseudomonas strain F113 was the only member of ARDRA group 3 (Fenton et al., 1992; Weller et al., 2007).

Various methods to analyze genetic diversity, such as random amplified polymorphic DNA (RAPD), denaturing gradient gel electrophoresis (DGGE), repetitive sequencebased (rep)-PCR with the BOXA1R primer (BOX-PCR), phlD restriction fragment length polymorphism (RFLP), were employed to reveal diversity among $p h l D^{+}$pseudomonads (Bergasma-Vlami et al., 2005; Keel et al., 1996; McSpadden Gardener et al., 2000; Weller et al., 2007). For example, BOX-PCR or RFLP and phylogenetic analysis of phlD identified at least 22 distinct $p h l D^{+}$genotypes, with 18 of them designated genotypes A-Q and T by using BOXPCR (Weller et al., 2007). Genotypes PfZ and PfY from wheat were identified by using RFLP and 16S rDNA gene sequence analysis (Mazzola et al., 2004). Genotypes S and $\mathrm{R}$ were isolated from the rhizosphere of corn and soybean and inhibited oomycete pathogen growth (McSpadden Gardener et al., 2005). It appears that there are at least six additional genotypes, which have not been fully described (Weller et al., 2007). Among the 22 genotypes, genotype D is predominant in Washington State TAD fields (Raaijmakers and Weller, 2001) and is considered to be primarily responsible for the take-all suppressiveness in those fields. D-genotype strains are "premier" colonists of wheat roots and are able to establish and sustain threshold population sizes $\left(>10^{5} \mathrm{cfu} / \mathrm{g}\right.$ of root) needed for pathogen suppre- ssion throughout the growing season (Raaijmakers and Weller, 2001; Weller et al., 2007). Genotypes B, E, and L also are found in Washington take-all suppressive fields but do not have "premier" rhizosphere competence (Landa et al., 2003; Weller et al., 2007). In addition to the D genotype, other genotypes (A, O, P, and Q) also were found in a longterm monoculture field at Mt. Vernon, WA (Landa et al., 2002b), which also was suppressive to take-all (Weller et al., 2007), but only genotypes D and P show premier rhizosphere competence on pea.

Plant species and varieties differentially enrich and support phlD ${ }^{+}$populations (Bergasma-Vlami et al., 2005; De La Fuente et al., 2006; Mazzola et al., 2004) and genotypes (Landa et al., 2002a; Landa et al., 2006; Mazzola et al., 2004; Picard et al., 2004), and 2,4-DAPG accumulation also varies among plant hosts (Bergasma-Vlami et al., 2005) and cultivars of the same crop (Kwak et al., 2012). For example, wheat, sugar beet and potato grown in a Dutch TAD soil supported threshold densities of $p h l D^{+}$ isolates and 145,50 , or $120 \mathrm{ng} 2,4-\mathrm{DAPG} / \mathrm{g}$ of root, respectively, but neither $p h l D^{+}$isolates nor 2,4-DAPG was detected on lily (Bergasma-Vlami et al., 2005). 2,4-DAPG production by $P$. protegens ( $P$. fluorescens) CHA0 was correlated with phlA expression, and using a reporter system it was shown that more 2,4-DAPG accumulated on wheat and corn than on bean and cucumber (Notz et al., 2001). Several studies (Kwak et al., 2012; Mazzola et al., 2004; Okubara et al., 2004; Okubara and Bonsall, 2008) have demonstrated that wheat varieties differentially support phlD ${ }^{+}$populations, genotypes and 2,4-DAPG accumulation on roots. Mazzola et al. (2004) showed that the population densities of $p h l D^{+}$isolates from four wheat varieties grown in apple orchard soils differed significantly. The variety 'Lewjain' supported densities of $>10^{5} \mathrm{cfu} / \mathrm{g}$ of root, but no phlD isolates were detected on 'Eltan'. Populations on 'Penawawa' and 'Lewjain' did not differ, but were 10-fold greater than those on 'Hill-81' and 'Madsen.' Frequencies of the four genotypes found in orchard soils differed on each variety.

Okubara et al. (2004) surveyed 27 wheat cultivars for the ability to support root colonization by strains Q8r1-96 (Dgenotype) and Q2-87 (B-genotype) and showed that cultivars varied in supportiveness of colonization. Okubara and Bonsall (2008) also showed that cultivar influenced the production of 2,4-DAPG. For example, Q8r1-96 produced $123 \mathrm{ng}$ of 2,4-DAPG per seedling on roots of cv. 'Tara', but Q2-87 produced only 3.6 ng of 2,4-DAPG per seedling on the same cultivar. On cv. 'Buchanan', both $p h l D^{+}$genotypes produced similar amounts of 2,4-DAPG but Q8r1-96 produced significantly more 2,4-DAPG on 'Tara' than on 'Buchanan'. The population densities of Q8r1-96 and Q287 on Tara and Buchanan were similar $\left(2 \times 10^{9} \mathrm{cfu} / \mathrm{g}\right)$ in a 
soil-free system (Okubara and Bonsall, 2008). These results suggest that antibiotic accumulation is governed by both bacterial and host components and differences among varieties could account for the variability among fields in the number of years of severe disease required before the onset of TAD and the robustness of suppression.

Pseudomonas brassicacearum (P. fluorescens) Q8r1-96. P. fluorescens Q8r1-96, now known as P. brassicacearum based on genome sequence analysis (Loper et al., 2012), was originally isolated from wheat grown in Quincy TAD soil in 1996. Strain Q8r1-96 is the 'type strain' of the D genotype and is a "premier" colonist of the wheat rhizosphere (Weller et al., 2007). Raaijmakers and Weller (2001) first demonstrated that P. brassicacearum Q8r1-96 has a unique affinity for wheat by comparing the rhizosphere competence of Q8r1-96, Q2-87 (B-genotype) and 1M1-96 (L-genotype), strains typical of $p h l D^{+}$genotypes found in Washington State TAD fields. Each strain was introduced individually into a take-all conducive soil and grown to wheat for eight consecutive 4-week cycles. Throughout the experiment the population size of Q8r1-96 remained above $10^{5} \mathrm{cfu} / \mathrm{g}$ of root and it was 100 - to 1000 -fold greater than densities of Q2-87 and 1M1-96 (Raaijmakers and Weller, 2001). Landa et al. (2003) then demonstrated that the unique rhizosphere competence of Q8r1-96 is a characteristic of all genotype $\mathrm{D}$ isolates regardless of their source.

Mavrodi et al. (2006b; 2006c) studied a series of genes $d s b A, p t s P$, orf $T$ and sss that were thought to contribute to the 'premier' rhizosphere competence of Q8r1-96. The $d s b A$ gene is predicted to function as a thiol-disulfide interchange protein. A $d s b A$ mutant had less motility and a different colony morphology than the wild type, and also produced 47\% more 2,4-DAPG than the wild type. The $p t s P$ and orf $T$ genes contribute to the pathogenicity of $P$. aeruginosa but clear functions are unknown. The sss gene encodes a recombinase and it contributes to the ability of the bacterium to adapt to new environments. All mutants colonized the wheat rhizosphere less than did the parental strain (Q8r196) when they were mixed with the wild-type. However only the pts $P$ mutant was less rhizosphere competent than Q8r1-96 when the two strains were introduced into the soil individually (Mavrodi et al., 2006c).

A recent comparative genome study of $P$. fluorescens Q2-87 and P. brassicacearum (P. fluorescens) Q8r1-96 showed that these strains have 5597 and 5717 genes in their respective genomes. Most surprising was the revelation that about $20 \%$ of the Q2-87 and Q8r1-96 genomes were different yet the two strains were near identical based on carbon and nitrogen utilization tests. Strains Q2-87 and Q8r1-96 contain 484 and 511 unique genes, respectively (Loper et al., 2012).
Biosynthesis and regulation of 2,4-diacetlyphloroglucinol. Biosynthesis of 2,4-diacteylphloroglucinol in Pseudomonas is encoded by the five-gene operon phlACBDE. $\mathrm{PhlD}$ is a key enzyme in 2,4-DAPG biosynthesis because it is required for the synthesis of phloroglucinol, a precursor to monoacetylphloroglucinol (MAPG) and 2,4-DAPG (Achkar et al., 2005). PhlD has homology with members of the chalcone synthase/stilbene synthase (CHS/STS) family of plant enzymes (Bangera and Thomashow, 1999; Raaijmakers et al., 2006). Downstream of phlACBD is phlE, which encodes an export protein and upstream are divergently transcribed $\mathrm{p} h l F, p h l G$ and $p h l H$ genes, encoding transcriptional regulators that repress expression of the biosynthesis operon. 2,4-DAPG controls its own biosynthesis by preventing the binding of the repressor phlF to the operator of the operon.

phlACBDE over-expression in $P$. protegens strain Pf-5 resulted in the production of two-fold more 2,4-DAPG than the wild type (Achkar et al., 2005). Production of 2,4DAPG is also dependent on host factors such as root exudates (Notz et al., 2001; Shanahan et al., 1992). Currently, more than 24 sigma factors have been reported in Pseudomonas spp. (Potvin et al., 2008). RpoD, a sigma factor over-expressed in P. protegens CHA0, enhanced 2,4DAPG and pyoluteorin production and also improved biocontrol ability (Schnider et al., 1995). Some studies claimed novel transcription factors as positive regulators of 2,4DAPG biosynthesis. A mvaT mvaV double mutant of $P$. protegens CHA0 completely shut down 2,4-DAPG biosynthesis. However, the double mutant produced up to 20fold more pyoluteorin than the wild type strain. mvaT and $m v a V$ are considered to be global regulators of antibiotic biosynthesis (Baehler et al., 2006).

2,4-DAPG has antiviral, antibacterial, antifungal, antihelminthic and phytotoxic activity (Weller et al., 2007). Keel et al. (1992) reported that the growth of most phytopathogenic fungi was completely inhibited at $128 \mu \mathrm{g} / \mathrm{ml}$ of 2,4-DAPG in vitro and G. graminis var. tritici was completely inhibited at $64 \mu \mathrm{g} / \mathrm{ml}$ of 2,4-DAPG. However, Mazzola et al. (1995) reported that $3 \mu \mathrm{g} / \mathrm{ml}$ of 2,4-DAPG can suppress the growth of $G$ graminis var. tritici. The reported difference in the sensitivity of $G$ graminis var. tritici to 2,4-DAPG is probably due to variation in isolates tested, source of 2,4-DAPG and conditions of the assays. There is also large variation in the antibacterial activity of 2,4-DAPG. Some Bacillus spp. were entirely suppressed by less than $5 \mu \mathrm{g} / \mathrm{ml}$ of 2,4-DAPG (Keel et al., 1992), whereas 2,4-DAPG-producing Pseudomonas spp. were not inhibited even at 1,000 $\mu \mathrm{g} / \mathrm{ml}$ of 2,4-DAPG. Generally, 2,4-DAPG was more toxic to dicotyledonous plants than monocotyledonous plants. Many monocotyledonous plants were inhibited at $256 \mu \mathrm{g} / \mathrm{ml}$ of 2,4-DAPG, whereas less than 128 
$\mu \mathrm{g} / \mathrm{ml}$ of 2,4-DAPG inhibited the growth of dicotyledonous plants (Keel et al., 1992).

\section{Role for 2,4-DAPG in Induced Systemic Resistance}

Some biocontrol pseudomonads can activate a plant defense system that is known as induced systemic resistance (ISR). P. protegens strain, CHA0 partially protected Arabidopsis thaliana from the oomycete Hyaloperonospora arabidopsidis (Peronospora parasitica) (Iavicoli et al., 2003). Among the various antibiotic-deficient mutants of strain CHA0 tested, only 2,4-DAPG-deficient mutants were significantly reduced in inducing ISR activity. Weller et al. (2012) also reported that 2,4-DAPG-producing P. fluorescens Q2-87 and other pseudomonads representing several different phlD ${ }^{+}$genotypes colonized Arabidopsis thaliana roots and induced resistance in the leaves against $P$. syringae pv. tomato. However 2,4-DAPG-deficient mutants of strain Q2-87 were significantly less effective than the wild type at inducing resistance. Genetic complementation of the mutants restored ISR activity back to wild-type levels. The ISR activity induced by the $p h l D^{+}$isolates was equivalent to that of the well-studied biocontrol agent $P$. fluorescens WCS417r. Like strain WCS417r, the ISR activity induced by 2,4DAPG-producing pseudomonads operates through the ethylene-and jasmonic acid-dependent signal transduction pathway. Collectively, these results indicate that the ability to induce resistance is a common trait among 2,4-DAPGproducing pseudomonads within the $P$. fluorescens complex.

Verhagen et al. (2004) used P. fluorescens WCS417r to induce resistance in Arabidopsis thaliana and showed that in the root, 97 genes changed their expression level with WCS417r treatment up to 7 days. In contrast, in leaves none of the 8,000 genes changed in response to root colonization by strain WCS417r. However, following inoculation of the leaves of the induced plants with $P$. syringae pv. tomato DC3000, 81 genes changed as compared to in a control that was not treated with WCS417r. The data demonstrate a key characteristic of ISR that plants that are induced by bacterial treatment have primed defense genes that respond stronger and faster when a pathogen attack occurs. This phenomenon is called 'priming' (Conrath et al., 2002; Verhagen et al., 2004; Tjamos et al., 2005; De vleesschauwer and Hfte, 2009).

\section{Mode of Action of 2,4-DAPG}

Many studies have demonstrated that plant pathogens have several mechanisms to protect themselves against toxic compounds. Pathogens can hydrolyze toxins by various enzymes (Morrissey et al., 1999); a mutation can occur in the pathogen making the molecular target of the toxin

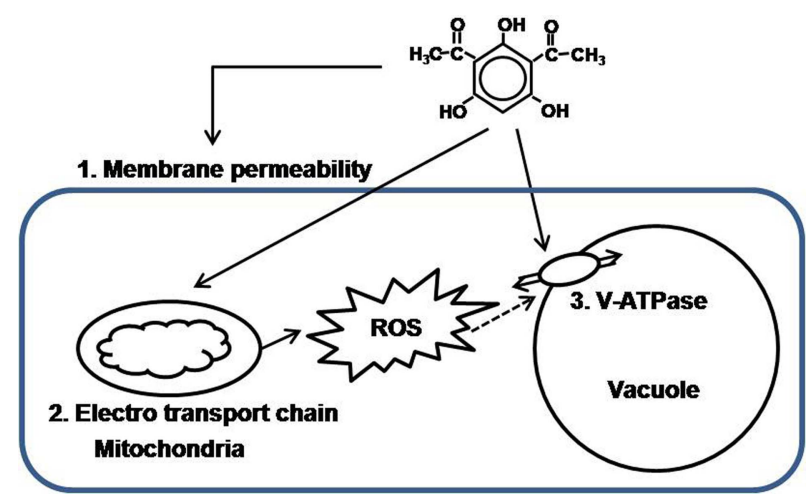

Fig. 3. A putative model for the mechanism of action of 2,4DAPG. 2,4-DAPG probably causes membrane damage, distribution of mitochondria electron transport chain and inhibition of VATPase activity.

unavailable or less available (van Etten et al., 2001); and/or pathogens can export toxic compounds out of the cell or into vacuoles through transport mechanisms (Fleissner et al., 2002). Even though many biological control studies have focused on the activities of antibiotic compounds produced by antagonists, only a few studies have actually addressed the mode-of-action of natural antibiotics (Duffy, 2003) at the molecular level. To determine possible mechanism(s) of action of the antibiotic 2,4-DAPG against the take-all pathogen G. graminis var. tritici, which lacks a genetic system to facilitate molecular studies, Kwak et al. (2011) used the Saccharomyces cerevisiae genome-wide mutant library to reveal eukaryotic responses to 2,4-DAPG. Among 5,154 mutants, 231 mutants were selected as sensitive to 2,4-DAPG. Chemical-genetic and biochemical analyses of the selected yeast mutants showed that three major physiological functions correlated with an increase in sensitivity to 2,4-DAPG: membrane permeability, regulation of reactive oxygen regulation, and cell homeostasis (Fig. 3). Thus, 2,4-DAPG probably attacks multiple basic cellular pathways in the take-all pathogen.

\section{Effect of 2,4-DAPG in Agro-ecosystems}

A major question in take-all decline is whether antibiotic resistance or tolerance has emerged in G. graminis var. tritici isolates in TAD fields as a result of years or even decades of exposure of the pathogen to 2,4-DAPG produced on wheat roots during wheat monoculture (Kwak et al., 2009). Mazzola et al. (1995) reported that isolates of the take-all pathogen showed differences in sensitivity to 2,4DAPG based on their geographic origin. Kwak et al. (2009) isolated over $250 \mathrm{G}$. graminis var. tritici isolates from TAD and non-TAD fields and on the basis of the $90 \%$ effective dose $\left(E D_{90}\right)$ value, placed isolates into the categories of "sensitive" $\left(\mathrm{ED}_{90}: 3.1\right.$ to $4.4 \mu \mathrm{g}$ of $\left.2,4-\mathrm{DAPG} / \mathrm{ml}\right)$, "mode- 
rately sensitive" $\left(\mathrm{ED}_{90}: 4.5\right.$ to $\left.6.1 \mu \mathrm{g} / \mathrm{ml}\right)$, and "less sensitive" $\left(\mathrm{ED}_{90}: 6.2\right.$ to $\left.11.1 \mu \mathrm{g} / \mathrm{ml}\right)$. The sensitivity of the isolates to 2,4-DAPG varied within a single field and among fields; however, there were no significant differences in sensitivity among isolates from TAD and non-TAD fields. In addition, there was no correlation between virulence of an isolate and 2,4-DAPG sensitivity. It was concluded that resistance or tolerance to 2,4-DAPG did not develop in the take-all pathogen even after long-term wheat monoculture. Several possible explanations were suggested to explain this result. First, because 2,4-DAPG attacks multiple basic cellular pathways, emergence of antibiotic resistance in the pathogen would be very unlikely. Second, G. graminis var. tritici may be exposed to inhibitory concentrations of 2,4DAPG only during its parasitic phase in sites such as in infection courts and lesions where $p h l D^{+}$pseudomonads proliferate. During the rest of the pathogen's life cycle, while growing saprophytically or surviving in crown and root tissues, the antibiotic may not be present or present at extremely low levels. This scenario would reduce the selection pressure on the pathogen for the emergence of resistant isolates, as compared to if the pathogen was exposed to the antibiotic throughout its life cycle. Finally, 2,4-DAPG could have a short half-life in the rhizosphere, thus limiting the exposure of the pathogen to the antibiotic (Kwak et al., 2009).

To address these possibilities, Kwak et al. (2012) determined the kinetics of 2,4-DAPG production and antibiotic stability in the wheat rhizosphere. Strain Q8r1-96 was introduced as a seed treatment onto wheat cultivars Tara and Buchanan and the rhizospheres of both cultivars became colonized to the same level with Q8r1-96. At 2, 3, and 4 weeks after planting, 320, 339, and $43 \mathrm{ng}$ of 2,4-DAPG/g of root was detected on Tara, but on Buchanan 1820, 557 and $71 \mathrm{ng} / \mathrm{g}$ of root was detected. When pure 2,4-DAPG was added to roots with attached rhizosphere soil, the antibiotic detected declined rapidly over time and the half-life of the antibiotic was calculated to be only about 6 hours (Kwak et al., 2012). These studies demonstrated that the wheat cultivar can impact both the accumulation and degradation of 2,4-DAPG in the rhizosphere, and that antibiotic production is likely to be greatest soon after $p h l D^{+}$pseudomonads colonize the root and when the take-all pathogen is most likely to begin infection.

\section{Summary}

Plants defend themselves against pathogens by multiple well-described mechanisms such as innate (non-host) immunity, localized race-specific resistance, and systemic resistance. Equally important are microbial-based mechanisms of root defense against soilborne pathogens that are modulated by the plant through root exudates, leading to the stimulation and support of populations of antagonistic rhizosphere microorganisms including Pseudomonas spp. This mechanism often constitutes the first line of defense against root-infecting soilborne pathogens. Disease-suppressive soils provide some of the best examples of indigenous microorganisms protecting plant roots against soilborne pathogens. Suppressive soils are known for many pathogens, occur worldwide, and provide highly effective and sustainable control of certain diseases with minimal offfarm inputs. Long-standing suppression is naturally associated with soil and is of unknown origin, whereas induced suppression develops as a result of a cropping practice, most commonly crop monoculture. One of the best known examples of natural soil suppressiveness is take-all decline (TAD), which develops during wheat or barley monoculture following an outbreak of take-all. The basis of TAD is the build-up of populations of fluorescent Pseudomonas spp. producing 2,4-DAPG and accumulation of the antibiotic in the rhizosphere. The take-all pathogen $G$. graminis var. tritici is highly sensitive to this antibiotic. Studies of the interactions among wheat roots, the take-all pathogen, 2,4-DAPG producers and the rhizosphere microbiome are providing fundamental new insights at the molecular level as to how indigenous microorganisms "hear the cry for help" and "come to the rescue" when wheat is attacked by soilborne pathogens.

\section{References}

Achkar, J., Xian, M., Zhao, H. and Frost, J. W. 2005. Biosynthesis of phloroglucinol. J. Am. Chem. Soc. 127:5332-5333.

Andersen, J. B., Koch, B., Nielsen, T. H., Sorensen, D., Hansen, M., Nybroe, O., Christophersen, C., Sorensen, J., Molin, S. and Givskov, M. 2003. Surface motility in Pseudomonas sp. DSS73 is required for efficient biological containment of the root-pathogenic microfungi Rhizoctonia solani and Pythium ultimum. Microbiology 149:37-46.

Baehler, E., de Werra, P., Wick, L. Y., Pechy-Tarr, M., Mathys, S., Maurhofer, M. and Keel, C. 2006. Two novel MvaT-like global regulators control exoproduct formation and biocontrol activity in root-associated Pseudomonas fluorescens CHA0. Mol. Plant-Microbe Interact. 19:313-329.

Baker, K. F. and Cook, R. J. 1974. Biological Control of Plant Pathogens. W.H. Freeman, San Francisco. 433pp.

Bangera, M. G. and Thomashow, L. S. 1999. Identification and characterization of a gene cluster for synthesis of the polyketide antibiotic 2,4-diacetylphloroglucinol from Pseudomonas fluorescens Q2-87. J. Bacteriol. 181:3155-3163.

Bergasma-Vlami, M., Prins, M. E. and Raaijmakers, J. M. 2005. Influence of plant species on population dynamics, genotypic diversity and antibiotic production in the rhizosphere by indigenous Pseudomonas spp. FEMS Microbiol. Ecol. 52:59-69.

Calvent, V., de Orellano, M. E., Sansone, G., Benuzzi, D. and de 
Tosetti, M. I. S. 2001. Effect of nitrogen source and $\mathrm{pH}$ on siderophore production by Rhodotorula strains and their application to biocontrol of phytopathogenic moulds. J. Ind. Microbiol. Biotechnol. 26:226-229.

Chet, I. and Inbar, J. 1994. Biological control of fungal pathogens. Appl. Biochem. Biotechnol. 48:37-43.

Conrath, U., Pieterse, C. M. J. and Mauch-Mani, B. 2002. Priming in plant-pathogen interaction. Trends Plant Sci. 7:210216.

Cook, R. J. and Rovira, A. D. 1976. The role of bacteria in the biological control of Gaeumannomyces graminis by suppressive soils. Soil Biol. Biochem. 8:269-273.

Cook, R. J., Thomashow, L. S., Weller, D. M., Fujimoto, D., Mazzola, M., Bangera, G. and Kim, D. S. 1995. Molecular mechanism of defense by rhizobacteria against root disease. Proc. Natl. Acad. Sci. USA 92:4179-4201.

Cook, R. J. 2003. Take-all of wheat. Physiol. Mol. Plant Pathol. 62:73-86.

Cronin, D., Moenne-Loccoz, T., Fenton, A., Dunne, C., Dowling, D. N. and O'Gara, F. 1997a. Ecological interaction of a biocontrol Pseudomonas fluorescens strain producing 2,4-diacetylphloroglucinol with the soft rot potato pathogen Erwinia carotovora subsp. atroseptica. FEMS Microbiol. Ecol. 23:95106.

Cronin, D., Moenne-Loccoz, T., Fenton, A., Dunne, C., Dowling, D. N. and O'Gara, F. 1997b. Role of 2,4-diacetylphloroglucinol in the interactions of the biocontrol pseudomonad strain F113 with the potato cyst nematode Globodera rostochiensis. Appl. Environ. Microbiol. 63:1357-1361.

D’aes, J., Hoang Hua, G. K., De Maeyer, K., Pannecoucque, J., Forrez, I., Ongena, M., Dietrich, L. E. P., Thomashow, L. S., Mavrodi, D. V. and Höfte, M. 2011. Biological control of Rhizoctonia root rot on bean by phenazine and cyclic lipopeptide-producing Pseudomonas CMR12a. Phytopathology 101:996-1004.

De La Fuente, L., Landa, B. B. and Weller, D. M. 2006. Host crop affects rhizosphere colonization and competitiveness of 2,4diacetylphloroglucinol-producing Pseudomonas fluorescens. Phytopathology 96:751-762.

De Vleesschauwer, D. and Hfte, M. 2009. Rhizobacteria-induced systemic resistance. Adv. Bot. Res. 51:223-281.

de Souza, J. T., Arnould, C., Deulvot, C., Lemanceau, P., Gianinazzi-Pearson, N. and Raajimakers, J. M. 2003a. Effect of 2,4diacetylphloroglucinol on Pythium: cellular responses and variation in sensitivity among propagules and species. Phytopathology 93:966-975.

de Souza, J. T., Weller, D. M. and Raaijmakers, J. M. 2003b. Frequency, diversity, and activity of 2,4-diacetylphloroglucinolproducing fluorescent Pseudomonas spp. in Dutch take-all decline soils. Phytopathology 93:54-63.

Duffy, B. K. and Défago, G. 1997. Zinc improves biocontrol of Fusarium crown and root rot of tomato by Pseudomonas fluorescens and represses the production of pathogen metabolites inhibitory to bacterial antibiotic biosynthesis. Phytopathology $87: 1250-1257$.

Duffy, B., Schouten, A. and Raaijmakers, J. M. 2003. Pathogen self-defense: mechanisms to counteract microbial antagonism. Annu. Rev. Phytopathol. 41:501-538.

Fenton, A. M., Stephens, P. M., Crowley, J., Ocallaghan, M. and O'Gara, F. 1992. Exploitation of gene(s) involved in 2,4diacetylphloroglucinol biosynthesis to confer a new biocontrol capability to a Pseudomonas strain. Appl. Environ. Microbiol. 58:3873-3878.

Fleissner, A., Sopalla, C. and Weltring, K. M. 2002. An ATPbinding cassette multidrug-resistance transporter is necessary for tolerance of Gibberella pulicaris to phytoalexins and virulence on potato tubers. Mol. Plant-Microbe Interact. 15:102108.

Fravel, D. R. 1992. Role of antibiosis in the biocontrol of plant diseases. Annu. Rev. Phytopathol. 26:75-91.

Freeman, J. and Ward, E. 2004. Gaeumannomyces graminis, the take-all fungus and its relatives. Mol. Plant Pathol. 5:235252.

Haas, D. and Défago, G. 2005. Biological control of soil-borne pathogens by fluorescent Pseudomonas. Nature Rev. Microbiol. 3:307-319.

Haas, D., Keel, C. and Reimmann, C. 2002. Signal transduction in plant-beneficial rhizobacteria with biocontrol properties. Antonie Leeuwenhoek 81:385-395.

Haas, D. and Keel, C. 2003. Regulation of antibiotic production in root-colonizing Pseudomonas spp. and relevance for biological control of plant disease. Annu. Rev. Phytopathol. 41:117153.

Hammer, P., Hill, D. S., Lam, S. T., van Pe, K. H. and Ligon, J. M. 1997. Four genes from Pseudomonas fluorescens that encode the biosynthesis of pyrrolnitrin. Appl. Environ. Microbiol. 63:2147-2154.

Hornby, D. 1998. Take-All of Cereals. A Regional Perspective. CAB International, Wallingford, UK.

Iavicoli, A., Boutet, E., Buchala, A. and Métraux, J. P. 2003 Induced systemic resistance in Arabidopsis thaliana in response to root inoculation with Pseudomonas fluorescens CHA0. Mol. Plant-Microbe Interact. 16:851-858.

Keel, C., Schnider, U., Maurhofer, M., Voisard, C., Laville, J., Burger, U., Wirthner, P., Haas, D. and Défago, G. 1992. Suppression of root diseases by Pseudomonas fluorescens CHA0: Important of the bacterial secondary metabolite 2,4-diacetylphloroglucinol. Mol. Plant-Microbe Interact. 5:4-13.

Keel, C., Weller, D. M., Natsch, A., Défago, G., Cook, R. J. and Thomashow, L. S. 1996. Conservation of the 2,4-diacetylphloroglucinol biosynthesis locus among fluorescent Pseudomonas strains from diverse geographic locations. Appl. Environ. Microbiol. 62:552-563.

Kollmorgen, J. F. and Walsgott, D. N. 1984. Saprophytic survival of Gaeumannomyces graminis var. tritici at various depths in soil. Trans. Brit. Mycol. Soc. 82:346-348.

Kwak, Y.-S., Bakker, P. A. H. M., Glandorf, D. C. M., Rice, J. T., Paulitz, T. C. and Weller D. M. 2009. Diversity, virulence, and 2,4-diacetylphloroglucinol sensitivity of Gaeumannomyces graminis var. tritici isolates from Washington State. Phytopathology 99:472-479.

Kwak, Y.-S., Bonsall, R. F., Okubara, P. A., Paulitz, T. C., Tho- 
mashow, L. S. and Weller, D. M. 2012. Factors impacting the activity of 2,4-diacetylphloroglucinol-producing Pseudomonas fluorescens against take-all of wheat. Soil Biol. Biochem. $54: 48-56$

Kwak, Y.-S., Han, S., Thomashow, L. S., Rice, J. T., Paulitz, T. C., Kim, D. and Weller, D. M. 2011. Saccharomyces cerevisiae genome-wide mutant screen for sensitivity to 2,4-diacetylphloroglucinol, an antibiotic produced by Pseudomonas fluorescens. Appl. Environ. Microbiol. 77:1770-1776.

Landa, B. B., de Werd, H. A. E., McSpadden-Gardener, B. B. and Weller, D. M. 2002a. Comparison of three methods for monitoring populations of different genotypes of 2,4-diacetylphloroglucinol-producing Pseudomonas fluorescens in the rhizosphere. Phytopathology 92:129-137.

Landa, B. B., Mavrodi, O. V., Raaijmakers, J. M., McSpaddenGardener, B. B., Thomashow, L. S. and Weller, D. M. 2002b. Differential ability of genotypes of 2,4-diacetylphloroglucinol-producing Pseudomonas fluorescens to colonize the roots of pea. Appl. Environ. Microbiol. 68: 3226-3237.

Landa, B. B., Mavrodi, D., Thomashow, L. S. and Weller, D. M. 2003. Interactions between strains of 2,4-diacetylphloroglucinol-producing Pseudomonas fluorescens in the rhizosphere of wheat. Phytopathology 93:982-994.

Landa, B. B., Mavrodi, O. V., Schroeder, K. L., Allende-Molar, R. and Weller, D. M. 2006. Enrichment and genotypic diversity of phlD-containing fluorescent Pseudomonas spp. in two soils after a century of wheat and flax monoculture. FEMS Microbiol. Ecol. 55:351-368.

Ligon, J. M., Hill, D. S., Hammer, P. E., Torkewitz, N. R., Horhmann, D., Kempf, H. J. and van Pe, H. H. 2000. Natural products with antifungal activity from Pseudomonas biocontrol bacteria. Pest Manag. Sci. 56:688-695.

Loper, J. E. and Gross, H. 2007. Genomic analysis of antifungal metabolite production by Pseudomonas fluorescens Pf-5. Eur. J. Plant Pathol. 119:265-278.

Loper, J. E., Hassan, K. A., Mavrodi, D. V., Davis II, E. W., Lim, C. K., Shaffer, B. T., Elbourne, L. D. H., Stockwell, V. O., Hartney, S. L., Breakwell, K., Henkels, M. D., Tetu, S. G., Rangel, L. I., Kidarsa, T. A., Wilson, N. L., van de Mortel, J. E., Song, C., Blumhagen, R., Radune, D., Hostetler, J. B., Brinkac, L. M., Durkin, A. S., Kluepfel, D. A., Wechter, W. P., Anderson, A. J., Kim, Y. C., Pierson III, L. S., Pierson, E. A., Lindow, S. E., Kobayashi, D. Y., Raaijmakers, J. M., Weller, D. M., Thomahsow, L. S., Allen, A. E. and Paulsen, I. T. 2012. Comparative genomics of plant-associated Pseudomonas spp.: Insights into diversity and inheritance of traits involved in multitrophic interactions. PLoS Genetics 8:e1002784.

Lugtenberg, B. J. J. and Kravchenoko, L. V. 1999. Tomato seed and root exudate sugars: composition, utilization by Pseudomonas biocontrol strains and role in rhizosphere colonization. Environ. Microbiol. 1:439-446.

Maurhofer, M., Keel, C., Haas, D. and Dfago, G. 1995. Influence of plant species on disease suppression by Pseudomonas fluorescens strain CHA0 with enhanced antibiotic production. Plant Pathol. 44:40-50.

Mavrodi, D. V., Blankenfeldt, W. and Thomashow, L. S. 2006a.
Phenazine compounds in fluorescent Pseudomonas spp. biosynthesis and regulation. Annu. Rev. Phytopathol. 44:417445.

Mavrodi, O. V., Mavrodi, D., Park, A. A., Weller, D. M. and Thomashow, L. S. 2006b. The role of $d s b A$ in colonization of the wheat rhizosphere by Pseudomonas fluorescens Q8r1-96. Microbiology 152:863-872.

Mavrodi, O. V., Mavrodi, D., Weller, D. M. and Thomashow, L. S. 2006c. Role of ptsP, orfT, and sss recombinase genes in root colonization by Pseudomonas fluorescens Q8r1-96. Appl. Environ. Microbiol. 72:7111-7122.

Mazzola, M., Fujimoto, D. K., Thomashow, L. S. and Cook, R. J. 1995. Variation in sensitivity of Gaeumannomyces graminis to antibiotics produced by fluorescent Pseudomonas spp. and effect on biological control of take-all of wheat. Appl. Environ. Microbiol. 61:2554-2559.

Mazzola, M., Funnell, D. L. and Raaijmakers, J. M. 2004. Wheat cultivar-specific selection of 2,4-diacetylphloroglucinol producing fluorescent Pseudomonas species from resident soil populations. Microbial Ecol. 48:338-348.

McSpadden Gardener, B. B., Schroeder, K. L., Kalloger, S. E., Raaijmakers, J. M., Thomashow, L. S. and Weller, D. M. 2000. Genotypic and phenotypic diversity of phlD-containing Pseudomonas isolated from rhizosphere of wheat. Appl. Environ. Microbiol. 66:1939-1946.

McSpadden Gardener, B. B., Mavrodi, D. V., Thomashow, L. S. and Weller, D. M. 2001. A rapid polymerase chain reactionbased assay characterizing rhizosphere populations of 2,4diacetylphloroglucinolproducing bacteria. Phytopathology 91: 44-54.

McSpadden-Gardener, B. B., Gutierrez, L. J., Joshi, R., Edema, R. and Lutton, E. 2005. Distribution and biocontrol potential of phlD Pseudomonas in corn and soybean fields. Phytopathology $95: 715-724$.

Moore, K. J. and Cook, R. J. 1984. Increased take-all of wheat with direct drilling in the Pacific Northwest. Phytopathology 74:1044-1049.

Morrissey, J. P. and Osbourn, A. E. 1999. Fungal resistance to plant antibiotics as a mechanism of pathogenesis. Microbiol. Mol. Biol. Rev. 63:708-724.

Notz, R., Maurhofer, M., Schnider-Keel, U., Duffy, B. K., Hass, D. and Défago, G. 2001. Biotic factors affecting expression of the 2,4-diacetylphloroglucinol biosynthesis gene phlA in Pseudomonas fluorescens biocontrol strain CHA0 in the rhizosphere. Phytopathology 91:873-883.

Okubara, P. A., Kornoely, J. P. and Landa, B. B. 2004. Rhizosphere colonization of hexaploid wheat by Pseudomonas fluorescens strains Q8r1-96 and Q2-87 is cultivar-variable and associated with changes in gross root morphology. Biol. Cont. 30:391-403.

Okubara, P. A. and Bonsall, R. F. 2008. Accumulation of Pseudomonas-derived 2,4-diacetylphloroglucinol on wheat seedling roots is influenced by host cultivar. Biol. Cont. 46:322-331.

Paulsen, I. T., Press, C., Ravel, J., Kobayashi, D. Y., Myers, G. S. A., Mavrodi, D. V., DeBoy, R. T., Seshadri, R., Ren, Q., Madupu, R., Dodson, R. J., Durkin, A. S., Brinkac, L. M., 
Daugherty, S. C., Sullivan, S. A., Rosovitz, M. J., Gwinn, M. L., Zhou, L., Nelson, W. C., Weidman, J., Watkins, K., Tran, K., Khouri, H., Pierson, E. A., Pierson III, L. S. Thomashow, L. S. and Loper, J. E. 2005. Complete genome sequence of the plant commensal Pseudomonas fluorescens Pf-5: insights into the biological control of plant disease. Nature Biotechnol. 23:873-878.

Picard, C., Frascaroli, E. and Bosco, M. 2004. Frequency and biodiversity of 2,4-diacetylphloroglucinol-producing rhizobacteria are differentially affected by the genotype of two maize inbred lines and their hybrid. FEMS Microbiol. Ecol. 49:207-215.

Pierson, E. A. and Weller, D. M. 1994. Use of mixtures of fluorescent Pseudomonads to suppress take-all and improve the growth of wheat. Phytopathology 84:940-947.

Potvin, E., Sanschagrin, F. and Levesque, R. C. 2008. Sigma factors in Pseudomonas aeruginosa. FEMS Microbiol. Rev. 32:38-55.

Raaijmakers, J. M., Bonsall, R. F. and Weller, D. M. 1999. Effect of population density of Pseudomonas fluorescens on production of 2,4-diacetylphloroglucinol in the rhizosphere of wheat. Phytopathology 89:470-475.

Raaijmakers, J. M., de Bruijn, I. and de Kock, M. J. D. 2006. Cyclic lipopeptide production by plant-associated Pseudomonas spp.: diversity, activity, biosynthesis, and regulation. Mol. Plant-Microbe Interact. 19:669-710.

Raaijmakers, J. M. and Weller, D. M. 1998. Natural plant protection by 2,4-diacetylphloroglucionl-producing Pseudomonas spp. in take-all decline soils. Mol. Plant-Microbe Interact. 11:144-152.

Raaijmakers, J. M. and Weller, D. M. 2001. Exploiting genotype diversity of 2,4-diasctylphloroglucinol producing Pseudomonas spp.: Characterization of superior root-colonizing P. fluorescens strain Q8r1-96. Appl. Environ. Microbiol. 67:25452554.

Ramette, A., Moenne-Loccoz, Y. and Défago, G. 2001. Polymorphism of the polyketide synthase gene phlD in biocontrol fluorescent pseudomonas producing 2,4-diacetylphloroglucinol and comparison of PhlD with plant polyketide synthases. Mol. Plant-Microbe Interact. 14:639-652.

Ran, H., Hassett, D. J. and Lau, G. W. 2003. Human targets of Pseudomonas aeruginosa pyocyanin. Proc. Nat. Acad. Sci. USA 100:14315-14320.

Schnider, U., Keel, C., Blumer, C., Troxler, J., Défago, G. and Haas, D. 1995. Amplification of the housekeeping sigma factor in Pseudomonas fluorescens CHA0 enhances antibiotic production and improves biocontrol abilities. J. Bacteriol. 117:5387-5393.

Shanahan, P., O'Sullivan, D. J., Simpson, P., Glennon, J. D. and O'Gara, F. 1992. Isolation of 2,4-diacetylphloroglucinol from a fluorescent pseudomonad and investigation of physiological parameters influencing its production. Appl. Environ. Microbiol. 58:353-358.
Smiley, R. W. and Cook, R. J. 1973. Relationship between take-all of wheat and rhizosphere $\mathrm{pH}$ in soils fertilized with ammonium vs. nitrate-nitrogen. Phytopathology 63:882-890.

Stutz, E. W., Défago, G. and Kern, H. 1986. Naturally occurring fluorescent Pseudomonas involved in suppression of block root rot of tobacco. Phytopathology 76:181-185.

Thomashow, L. S. 1996. Biological control of plant root pathogens. Curr. Opin. Biotechnol. 7:343-347.

Thomashow, L. S. and Weller, D. M. 1988. Role of a phenazine antibiotic from Pseudomonas fluorescens in biological control of Gaeumannomyces graminis var. tritici. J. Bacteriol. 170:3499-3508.

Tjamos, S., Flemetakis, E., Paplomatas, E. and Katinakis, P. 2005. Induction of resistance to Verticillium dahliae in Arabidopsis thaliana by the biocontrol agent K-165 and pathogenesisrelated proteins gene expression. Mol. Plant-Microbe Interact. 18:555-561.

van Etten, H., Temporini, E. and Wasmann, C. 2001. Phytoalexin (and phytoanticipin) tolerance as a virulence trait: why is it not required by all pathogens? Physiol. Mol. Plant Pathol. 59:8393.

Verhagen, B. M., Glazebrook, J., Zhu, T., Chang, H. S., van Loon, L. C. and Pieterse, C. M. 2004. The transcriptome of rhizobacteria induced systemic resistance in Arabidopsis. Mol. PlantMicrobe Interact. 17:895-908.

Voisard, C., Keel, C., Haas, D. and Défago, G. 1989. Cyanide production by Pseudomonas fluorescens helps suppress black root rot of tobacco under gnotobiotic conditions. EMBO J. 8:351-358.

Wang, C. X., Ramette, A., Punjasamarnwong, P., Zala, M., Natsch, A., Moenne-Loccoz, Y. and Défago, G. 2001. Cosmopolitan distribution of phlD-containing dicotyledonous cropassociated biocontrol pseudomonads of worldwide origin. FEMS Microbiol. Ecol. 37:105-116.

Weller, D. M. 1988. Biological control of soilborne plant pathogens in the rhizosphere with bacteria. Annu. Rev. Phytopathol. 26:379-417.

Weller, D. M., Landa, B. B., Mavrodi, O. V., Schroeder, K. L., De La Fuente, L., Bankhead, B. S., Allende Molar, R., Bonsall, R. F., Mavrodi, D. and Thomashow, L. S. 2007. Role of 2,4diacetylphloroglucinol-producing fluorescent Pseudomonas spp. in the defense of plant roots. Plant Biol. 9:4-20.

Weller, D. M., Raaijmakers, J. M., McSpadden-Gardener, B. B. and Thomashow, L. S. 2002. Microbial populations responsible for specific soil suppressiveness to plant pathogens. Annu. Rev. Phytopathol. 40:309-348.

Weller, D. M., Marrodi, D. V., van Pelt, J. A., Pieterse, C. M., van Loon, L. C. and Bakker, P. A. H. M. 2012. Induced systemic resistance in Arabidopsis thaliana against Pseudomonas syringae pv. tomato by 2,4-diacetylphloroglucinol-producing Pseudomonas fluorescens. Phytopathology 102:403-412.

Wiese, M. V. 1987. Compendium of Wheat Disease. Second Edition. APS Press, St. Paul, Minnesota. 